\title{
SZENZORHÁLÓZATOK ADATAINAK INTEGRÁLÁSI LEHETŐSÉGEI A PERSPEKTIVIKUS ERÖKÖVETÉSI RENDSZEREKBE, KÜLÖNÖS TEKINTETTEL AZ EGYÉNI EGÉSZSÉGÜGYI ADATOKRA
}

\section{SENSOR NETWORK DATA INTEGRATIONS TO PERSPECTIVE BLUE FORCE TRACKING SYSTEMS, ESPECIALLY TO MEDICAL DATA}

\author{
KÁROLY Krisztián \\ (ORCID: 0000-0002-5835-7980) \\ krisztian.karoly@mil.hu
}

\begin{abstract}
Absztrakt
Napjainkban komoly igényként jelentkezik, hogy a nyomon követett személyek, gép- és harcjármüvek, robotok geolokációs adatain túl harcképességüket, egészségügyi adataikat, a személy és a technikai eszközök készleteinek feltöltöttségét is közel valós időben nyomon lehessen követni. A jövő erökövetö hálózataiban várhatóan már megvalósulhatnak a szenzorhálózatokból kinyert adatok eszközeszköz közötti automatizált információcseréje. Kutatásomban vizsgálom az elsődlegesen egészségügyi adatok monitorozását végzö szenzorhálózatokból érkező adatok becsatornázási lehetöségeit, kiemelt figyelmet fordítva az IEEE 802.15.4 szabványú Zigbee eljárásra.

A kutatás az emberi eröforrások minisztériuma únkp-18-3-IV-NKE-27 kódszámú Új Nemzeti Kiválóság Programjának támogatásával készült
\end{abstract}

Kulcsszavak: Zigbee, szenzorhálózat, erökövetés, loT

\begin{abstract}
There is a serious demand nowadays, that we can track geo-location of the warriors, (fighting) vehicle and robots, moreover it would be trackable near real time the combat capability and medical data of person, and the charge level of technical equipment. In the perspective blue force tracking systems would take place machine to machine (M2M) exchanging sensor network data. Primary I research for medical data monitoring sensor networks, paying special attention to IEEE 802.14.5 ZigBee.
\end{abstract}

Keywords: Zigbee, sensor network, blue force trakcing, IoT 


\section{BEVEZETÉS}

Napjainkban komoly igényként jelentkezik, hogy a nyomon követett személyek, gép- és harcjármüvek, robotok geolokációs adatain túl harcképességüket, egészségügyi adataikat, a személy és a technikai eszközök készleteinek feltöltöttségét is közel valós időben nyomon lehessen követni. A jövő erőkövető hálózataiban várhatóan már megvalósulhat a szenzorhálózatokból kinyert adatok eszköz-eszköz ( $\left.\mathrm{M}^{2} \mathrm{M}^{1}\right)$ közötti automatizált információcseréje. Ezen hálózatok kiterjedésük szerint széles skálán tagozódhatnak, egészen az emberi test kiterjedésű $\left(\mathrm{BAN}^{2}\right)$ hálózatoktól, a személyes $\left(\mathrm{PAN}^{3}\right)$ és lokális (pl.: egy menetoszlop) hálózatokig, melyek az adatok feldolgozását követően az információkat szintén automatizáltan továbbítják egy távoli állomásnak, hálózatnak, esetleg felhőbe, vagy a helyi hálózatban egy személy részére (pl.: egészségügyi szakszemélyzet - egészségügyi adatok, ellátó altiszt - lőszerfogyás). Korunk haladó információtechnológiai megoldásainak köszönhetően ezen rendszerek a tudományos-fantasztikus világból kiemelkedve egyre inkább valóságos formát öltenek. Egy korábbi tudományos kutatás keretében már vizsgálták a katonák harci képességeit növelő korszerü, hálózatba integrált egyéni felszerelések alkalmazási lehetőségeit [1], melyben behatárolásra kerültek a lehetséges monitorozandó képességek, úgy mint $\mathrm{ABV}^{4}$, idegen-barát azonosítás, fegyverzet, a felszerelés energiaellátása, egyéni egészségi állapotellenőrzés és -jelentés, stb. Ezen feltárt területeket, mint diszciplínákat kezelem a szenzorhálózatok kiépülési területeinek tekintetében.

A témában jelentős tudományos munkák alapján [1] [2], a közeljövő menetoszlopaiban az oszlopparancsnok, vagy a távoli ellátási pont szakembere képes monitorozni a gép- és harcjármüvekben kiépített, egymással automatizáltan kommunikáló szenzorhálózatok segítségével az üzemanyag- és lőszerfogyást, a katonák egyéni felszereléseinek feltöltöttségét. A BAN hálózatoknak köszönhetően a katona harcképességét, egyéni egészségügyi adatait, illetve sebesültellátás során a sérültek triázsolása ${ }^{5}$ közel valós idejü, objektív, mérési adatok támogatásával történhet.

\section{A harci képességet növelő korszerű, hálózatba integrált szenzorrendszer kialakítási lehetőségei}

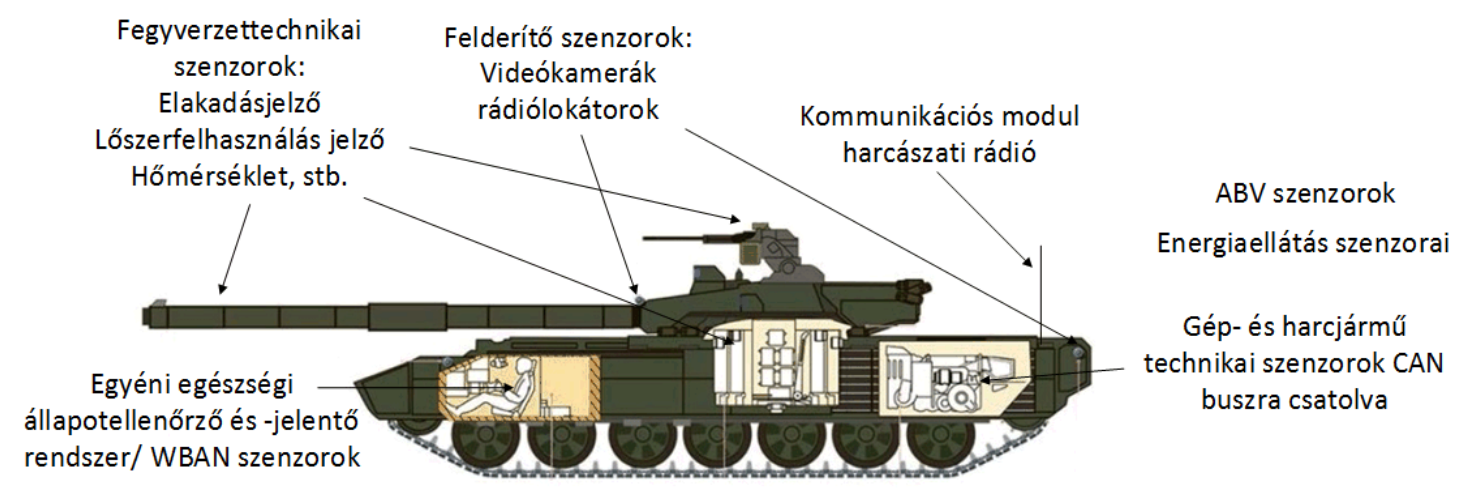

1. ábra A harci képességet növelő korszerü, hálózatba integrált szenzorrendszer kialakítási lehetőségei (szerkesztette a szerző, grafika: [3] $)^{6}$

\footnotetext{
${ }^{1}$ Machine to Machine - eszköz- eszköz közötti autonóm átvitel

${ }^{2}$ Body Area Network

${ }^{3}$ Personal Area Network

${ }^{4}$ Atom, Biológiai, Vegyi

${ }^{5}$ rangsorolás

${ }^{6}$ CAN - Contoller Area Network
} 
A szenzorosan monitorozható rendszerek, tulajdonságok (anyagi feltöltöttség, egészségi adatok) széles spektrumú kiterjedtsége folytán, a katona egyéni egészségi állapotellenőrzésének és -jelentésének lehetőségét vizsgálom mélyebben.

A BAN és PAN rendszerek kialakítására az esetek többségében ideálisan vezeték nélküli összeköttetési megoldásokat célszerü alkalmazni. Az $\operatorname{IEEE}^{7}$ szervezet a 802.15.4 alacsony adatrátájú vezeték nélküli személyi kiterjedésű hálózatok (WPAN ${ }^{8}$ ) szabványának egyes technológiáit jellemzően az egészségügyi adatok nyomon követésének biztosítására fejlesztették ki. Azonban, ahhoz hogy ezen szenzorhálózatokat kialakítsuk, szükséges behatárolni a monitorozni kívánt egészségügyi adatok körét.

Az adatok egészségügyi monitorozásának jogszabályi kérdéseit már egy korábbi publikációmban részletesen vizsgáltam [4].

\section{AZ ERŐKÖVETÉS SZEMPONTJÁBÓL KIEMELT SZENZOROSAN MONITOROZHATÓ EGÉSZSÉGÜGYI ADATOK}

Az egyéni egészségi állapotellenőrzés és -jelentés rendszer kialakítása során olyan automatizált, szenzorosan mért élettani adatokat szükséges összegyüjteni, melyek kiértékelésével komplex képet kaphatunk a személy harcképességéröl. Olyan non-invazív, azaz beavatkozás nélküli eljárásokat célszerü kiválasztani, amelyek alkalmazása során azok ergonomikusan illeszkednek a katona tevékenységéhez. Az invazív eljárással testbe beültetésre kerülö vezeték nélküli szenzorokat nem vizsgálom. Irodalomkutatásom és mélyinterjúim során [5], az alábbi eljárásokat határoltam be, mint az egyén egészségi állapotát komplexen megjelenítő mintavételezési módszerek. A személy elektrokardiográfiás (EKG) és elektroenkefalográfiás (EEG), valamint plethysmográfiás vizsgálata, továbbá a pulzus, az oxigénszaturáció, a testhőmérséklet és a vérnyomás mérése, a légzés ellenőrzése mozgásszenzorok felhasználásával, illetve a fiziológiai adatok vizsgálata, melyek még egyelőre nehezebben kivitelezhetök (pl. verejték összetételének elemzése) [6] [7].

Az elektrokardiográfia egy olyan non-invazív diagnosztikai eljárás, amely a szív elektromos jelenségeit vizsgálja a szívizom összehúzódásakor keletkező elektromos feszültség regisztrálásával. A szív összehúzódása a szinuszcsomóból induló elektromos inger hatására jön létre. Ez az inger a szív ingerületvezető rostjain keresztül a szívizomsejtekhez jut. Mivel az emberi test elektrolit oldatai jól vezetik a szívben lejátszódó folyamatokat, ezek az emberi test felszínén is jól érzékelhetőek. A kirajzolódó EKG hullám egyedi sajátosságokkal rendelkező szabályos görbe, melynek elemzésével megállapítható, hogy a szív ritmusosan ver-e, illetve normálisan terjed-e az akciós potenciál. Az EKG hullám kirajzolása a testfelszín meghatározott pontjaira elhelyezett (mellkas, hát, és végtagok) elektromos érzékelök által gyüjtött adatok felhasználásával történik. Az így kinyert adatok alapján megállapítható az egyén halála (asystolia), a szív különböző szegmenseiben fellépő zavarokból (sinuatrialis-, kamrai-, pitvari tachycardia, bradycardia, fibrillációk, stb.) láthatók a harcképesség csökkenés okai, az esetleges elszenvedett sokk hatásai [6] [7]. A szenzorok elhelyezhetők a katona közvetlenül testfelületét borító alsóöltözetében (felső testrész, pl.: póló), illetve a csuklón elhelyezkedő karkötőn és bakancsba építve. Napjainkban, ismereteim szerint még nem rendelkezünk kész termékekkel, azonban intenzív $\mathrm{K}+\mathrm{F}+\mathrm{I}$ tevékenység zajlik ruhanemükbe épített, hordható szenzorok kialakítását illetően [8].

Az elektorenkefalográfia az idegsejtek elektromos aktivitását vizsgálja valós időben. Esetünkben csak a non-invazív diagnosztikai eljárásokat tárgyalom, mivel azok akár harctéren is kivitelezhetők. A vizsgálatok során 31, 61 vagy 123 elektródát helyeznek el négy anatómiai referenciapont körül elöre meghatározott elv alapján, a hajas fejbőrön, esetenként az arcon is.

\footnotetext{
${ }^{7}$ Institute of Electrical and Electronics Engineers

${ }^{8}$ Wireless Area Network
} 
A szenzorok a katona egyéni védőeszközében, a sisakban, illetve maszkokban (hővédő, fizikai behatásoktól védő) célszerü elhelyezni. Sisakban történő elhelyezésnél a szenzorok vezetékkel is összeköthetők, így központilag megoldható az energiaellátás. Fontos kritérium, hogy az így kialakított sisak tömege lényegesen ne növekedjen, mert az a katona nyaki izmainak korai fáradását eredményezné. Az EEG vizsgálatok során mindig két elektróda közötti potenciálkülönbséget mérnek. Az EEG mérés a központi idegrendszer által generált nagy mennyiségü elektrofiziológiás aktivitást méri a koponyára kivetített állapotában.

A megfelelő helyzetkép kialakításához megszakítás nélküli, folytonos mérésekre van szükség, melynek komoly korlátja az akkumulátorok rendelkezésre álló kapacitása. Az EEG 20-30 perces mérési periódusa alapján megállapítható az agyhalál ténye, a kómába esés, az alvás mélysége, minősége, továbbá az éberségi állapotok elemezhetők a különböző kirajzolódó görbék alapján. Az éberségi állapotok, és alvási fázisok $\left(\mathrm{REM}^{9}, \mathrm{NREM}^{10}\right)$ százalékos eloszlásának meghatározásával objektív mérések alapján hozzávetőleges képet kaphatunk az egyén kifáradásának státuszáról [6] [7]. AZ EEG szenzorok harctéri alkalmazhatósága, és felszerelésbe integrálási lehetőségei, az EKG szenzorokhoz hasonlóan, még pre-kompetitív kutatások tárgyát képezi.

A katonák harcképességének plethysmográfiás vizsgálatait, azaz a térfogatváltozás nyomon követéséből a következő csoportokat emelem ki. Egyrészt a légzés során a tüdő tágulásának és összehúzódásának monitorozása, giroszkópos-mozgásszenzoros kiegészítéssel. Másik oldalról a fotóplethysmográfia (PPG) révén az erek térfogatváltozása figyelhető meg. A PPG eljárás talán egyik legismertebb formája a pulzusmérés.

Napjainkban már számtalan a pulzus mérésére alkalmas szenzor (pl.: sport órák, okoskarkötők) érhető el, amelyek por-, víz-, és rezgés ellenálló képességükkel megközelítik a katonai alkalmazásban használt színvonalat. A bemutatott mérési eljárások közül ez a terület áll a legközelebb, a mindennapokban a harctéren is alkalmazható kézzelfogható termék/ szenzor megalkotásához. A pulzus definíció szerint a periférián tapintható szívverések száma, ellentétben az EKG-s mérési eljárással, ahol a szív közvetlen környezetéböl nyernek információkat. Gyakori mintavételezési pontok a testen: a csuklón, a nyak oldalán futó verőér kitapintásával, a térdartérián, a karizmon, a combverőeren, a lábfejen. A legelterjedtebb szenzoros megvalósulás jelenleg a csuklón elhelyezett LED $^{11}$ alapú, fotós mintavételezés. A vér elnyeli a zöld fényt, és visszaveri a vöröset, így a szenzorokba épített zöld színü LED-ek segítségével a fényérzékeny fotódiódák képesek megállapítani az elnyelt fény mennyiségét. A szív dobbanásakor a csukló artériájában átfolyó véráramlás fokozódik, ezzel együtt a zöld fény elnyelése is. A dobbanások között mérsékeltebb a véráramlás. A szenzorok percenként több száz mintavételezést hajtanak végre, melyből nyomon követhető a pulzus, jellemzően 30-210 szívverés/ perc mintavételezési korlátok között [6] [7].

Az oxigénszaturáció mérésére szolgáló, non-invazív fotó alapủ pulzoximetria mérés hasonló mérőbázison alapul a PPG eljárással. A szöveteken áthaladó fénynyaláb intenzitását az artériás pulzáció modulálja. Ezt a nyalábot elektromos jellé alakítva egy maghatározott amplitúdójú pulzáló jelalakot kapunk. A vér oxigéntelítettségétöl függ a vér fényelnyelési képessége, és ez az elnyelési képesség generálja a pulzáció amplitúdóját. Két hullámhosszon mérve két pulzáló jelet kapunk, melyeknek amplitúdóinak arányából megállapítható az oxigén telítettség mértéke. Ezen szenzorok segítségével pár százalék hibahatárral megmérhető az oxigenizált hemoglobin szaturációja. Az artériás oxigenizált hemoglobin szaturációjának mérésével diagnosztizálható az esetleges csökkent oxigén ellátottság, azaz hypoxemia. A csökkent oxigén ellátottság diagnosztizálásával következtetni lehet a katona harcképességének csökkenésére [9]. A pulzusés pulzoximetria mérést célszerű integrált formában, egy komplex kialakítású szenzorral mérni.

\footnotetext{
${ }^{9}$ Rapid Eye Movement

${ }^{10}$ Non-Rapid Eye Movement

${ }^{11}$ Light Emitted Diode
} 
A harcos testhömérsékletének nyomon követésével megállapítható a túlhevülés (hyperthermia) és a kihülés (hypothermia) ténye, mely alapvetően befolyásolja a katona komfortérzetét, harcképességét, végső soron ezen állapotok sokkot, a szervezet visszafordíthatatlan károsodását, esetleg halált is okozhatnak.

A vérnyomás a keringési rendszerben a vérnek az erek falára kifejtett nyomása [8], továbblépve a vérpálya központi és környéki része közötti nyomáskülönbség hozzájárul a vérkeringés fenntartásához. A vér felelős a tápanyagok, oxigén, szabályozó anyagok szállításáért a test különböző szerveihez, illetve az anyagcsere termékek elszállításáért. A normális vérnyomás értékek függnek az egyén életkorától, testsúlyától, egy egészséges felnőtt ember kívánatos szisztolés (szív összehúzódása által kifejtett nyomás) vérnyomás értékei 90119 Hgmm, és diasztolés (szív elernyedése során bekövetkező nyomásérték) vérnyomás értékei 60-79 Hgmm. Az alacsony vérnyomás (hypotenzio) jellemzően 90/60 Hgmm (szisztolés/ diasztolés) alatti értékek, melyek alapesetben nem okoznak problémát, azonban vezethetnek ájuláshoz, levertséghez, aluszékonysághoz, fáradtsághoz, szédüléshez, tehát a katona harcképtelenségét okozhatják. A magas vérnyomást az alábbiak szerint skálázzuk, a 1. fokozatú hypertónia (140-159/90-99 Hgmm - szisztolés/diasztolés), 2. fokozatú hypertónia (160179/100-109 Hgmm - szisztolés/diasztolés), illetve a hypertóniás krízis (180/110 Hgmm szisztolés/diasztolés nyomásértékek felett). A magas vérnyomás, kiemelten a hypertóniás krízis komolyan befolyásolhatja a katona harcképességét. Okozhat többek között fejfájást, émelygést, zavartságot, a szemfenék bevérzését, rosszabb esetben infarktust, tüdőödémát, heveny vesekárosodást, a vérsejtek pusztulását. A vérnyomás mérése az orvosi praxisban széles körben alkalmazott diagnosztikai eljárás [10] [11] [12].

A vérnyomás mérése non-invazív eljárással a vérnyomásmérő müszerrel történik. A mintavételezési pont tekintetében lehet a felkaron, a csuklón elhelyezett vérnyomásmérővel, esetleg a kisujjon a vérvolumen - és áramlásváltozás alapján mérhető meg a vérnyomás. A csuklón történő vérnyomásmérés problematikája, hogy helyes mérési eredmény érdekében a csuklót a szívvel megegyező magasságba kell emelni, különben a hidrosztatikai nyomás 20-30 Hgmm-rel is meghamisíthatja a mérést, azonban ez a napi feladat végrehajtás során rendkívül körülményes. A vérnyomásmérő öt fö részből áll, az érszakaszt körülölelő szövetzsák, az úgynevezett mandzsetta, melynek feladata a pumpa által létrehozott nyomással, az izmok és kötőszövetek nyomásvezetésével az eret a csonthoz szorítja, ezzel elzárva a vér útját. A nyomás megszünésével a szisztolés vérnyomás során megjelenik a pulzus, majd ismételten eltünik (diasztolés nyomás). Az ér ismét feltelik vérrel, ezt a nyomásváltozást mérjük meg [10] [11] [12]. A nyomásváltozás sebességének beállítása, a müszer kalibrációját mikroprocesszor vezérli a $\mathrm{WBAN}^{12}$ hálózatokban alkalmazott modern elektronikus szenzorokban. A diagnosztikai eljárás hátránya, hogy a periodikus időközönként elvégzett mérések diszkomfort érzetet válthatnak ki a katonákból, a fokozott fizikai megterhelés során tovább növelhetjük perifériás vérnyomásukat, esetlegesen a sérülteknél, kifejezetten a roncsolásos, végtagvesztéses, mellkasi sérüléses esetekben az automatizált vérnyomásmérés irreverzibilis problémákat okozhat. Ezért célszerübb egy ideiglenes, eltávolítható WBAN szenzorként alkalmazni a vérnyomásmérőt, a korábban bemutatott, akár rendszeresen viselhető, hordható szenzorokkal ellentétben.

A bemutatott élettani tulajdonságokat mérő szenzorokat célszerü rendszerbe integráltan WBAN hálózatba kötve alkalmazni. Egyes szenzorok esetében lehetőség van vezetékkel összekötni azokat (pl.: sisakon belüli EEG elektródák, aláöltözetbe helyezett EKG szenzorok) egyazon felszerelési tárgyon belül, amelyek így közös energiaellátásban részesülhetnek. Azonban ezeket az egységeket is vezeték nélküli módon célszerü magasabb szintủ hálózatba szervezni.

\footnotetext{
${ }^{12}$ Wireless Body Area Network
} 


\section{Egyéni egészségi állapotellenőrző és -jelentő rendszert támogató WBAN szenzorok}

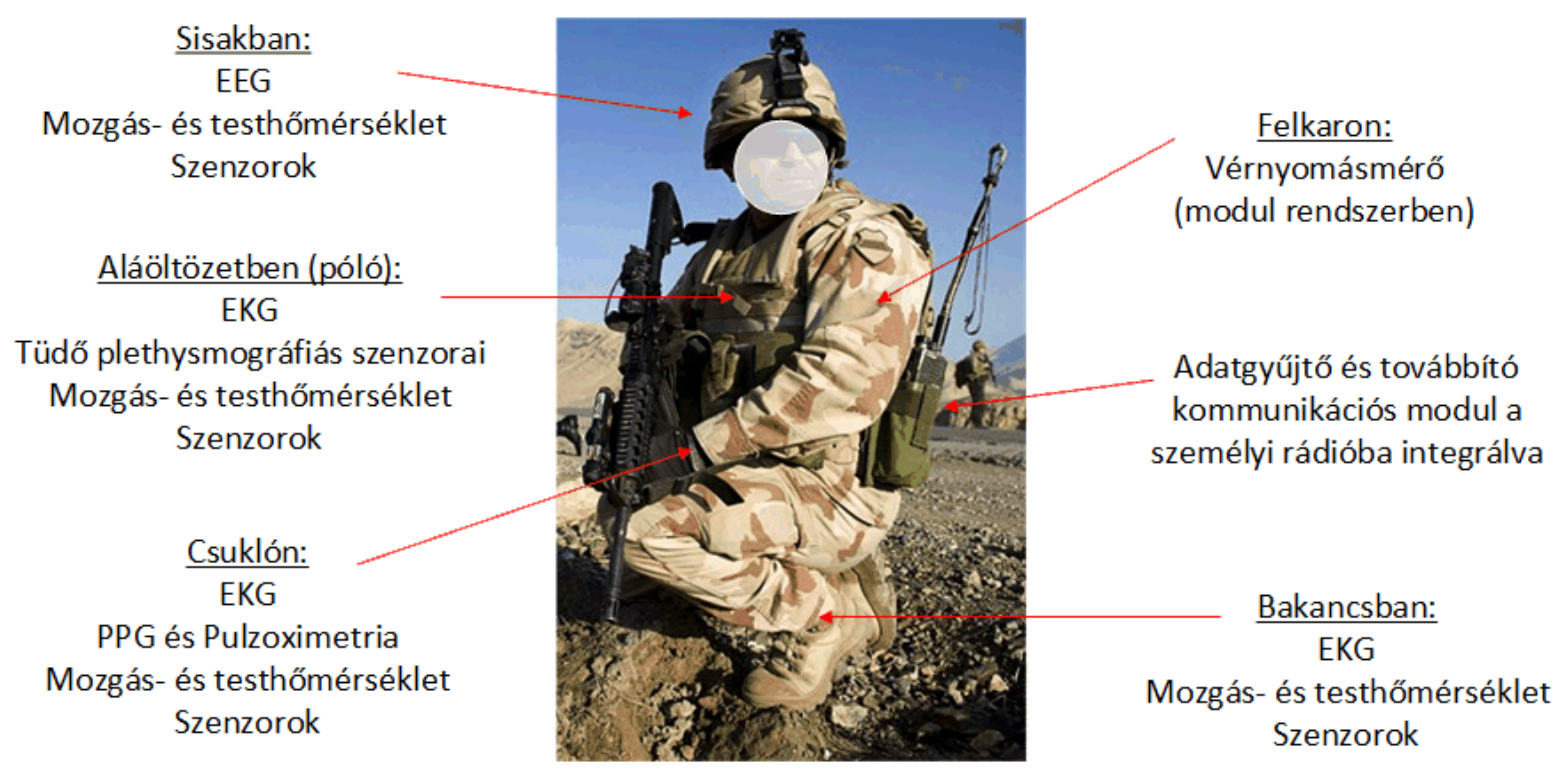

2. ábra Egyéni egészségi állapotellenőrző és -jelentő rendszert támogató WBAN szenzorok (szerkesztett a szerző - fotó: Koszticsák Szilárd - MTI $\left.{ }^{13}[13]\right)$

Megítélésem szerint célszerủ a katona személyi felszerelésében egy a szenzorhálózatok által biztosított adatok fogadására, rendszerezésére, első lépcsős feldolgozására, a különböző adatok egymással történő fuzionálására alkalmas személyi egészségügyi szerver elhelyezése. A szerver kialakításra kerülhet komplex módon az egyéni kommunikációs eszközben is a mai okostelefonok analógiájára, ahol a mobilhálózatokhoz történő hozzáférés mellett, az eszköz képes a WPAN hálózatból kinyert adatok feldolgozására, esetleg továbbküldésére távoli rendszerekbe. Egy lehetséges ilyen eszköz lehet egy TETRA ${ }^{14}-$ LTE $^{15}$ terminál a megfelelö vezeték nélküli kommunikációs eljárással, és a hozzá tartozó applikációval/ szoftverrel. Vagy a személyi harcászati rádió ellátása megfelelő interfészekkel, és az adatok feldolgozásához, tárolásához és továbbítására alkalmas technológiákkal.

\section{ZIGBEE}

Elvégzett irodalomkutatásaim alapján az IEEE 802.15.4 szabványú kommunikációs eljárások kiváltképp alkalmasak WBAN hálózatok kialakítására. A szabványban felsorolt protokollok közül a ZigBee technológiát vizsgáltam [14] [15] az egyéni egészségi állapotellenőrzés és jelentés rendszer kialakítása szempontjából.

A Zigbee kommunikációs eljárást a Zigbee Alliance fejlesztette ki, melyet 2006-ban szabványosítottak. Elsődleges felhasználási területe az alacsony adatforgalmat bonyolító, azonban energiaellátás szempontjából kritikus (ritkán feltölthető, alacsony fogyasztású) rendszerek.

Zigbee Alliance az OSI $^{16}$ modell fizikai rétegétől az alkalmazási rétegig fogalmaz meg ajánlásokat, illetve az IEEE szervezet az 802.15.4 szabványában dolgozta ki a Zigbee fizikai és

\footnotetext{
${ }^{13}$ Magyar Távirati Iroda

14 Terrestrial Trunked Radio

${ }^{15}$ Long Term Evolution - 4. Generációs mobilkommunikációs adatátvitel

${ }^{16}$ Open System Interconnection Reference Model
} 
közeghozzáférés vezérlő $\left(\mathrm{MAC}^{17}\right)$ rétegeinek müködését. A Zigbee rádiós interfésze három különböző frekvenciatartományban müködik, a 2,4 GHz-es ISM ${ }^{18}$ sávban, az amerikai 915 MHz-es ISM sávban, és a Európában $868 \mathrm{MHz}$-es ISM sávban. A 2,4 GHz-es ISM sávban 2,405 GHz-től 2,480 GHz-ig 5MHz-enként került felosztásra a 16 csatorna. A fizikai csatorna elméleti átviteli sebessége 20 - 250 kpbs-ig terjed, amely maximum 128 kbps valós adatátviteli sebességet jelent. A rendszer direkt szekvenciális spektrumszórást alkalmaz az interferenciák kivédése érdekében. A fizikai réteg elméleti 250 kbps-os átviteli sebességéhez 62,5 ezer szimbólum/ másodperc tartozik. A DSSS ${ }^{19} 1$ bitet 4 chip segítségével határoz meg. Az alkalmazott frekvenciák mikrohullámú terjedési tulajdonságot mutatnak. A gyakorlati tapasztalatok alapján maximum 10-20 m hatótávolsággal érdemes számolni, amely WBAN hálózatok esetén kielégítő. A Zigbee frekvenciatartományai a következő ábrán láthatók [15].

\begin{tabular}{|l|l|l|l|l|l|l|l|}
\hline Frekvencia & Sáv & Lefedettség & $\begin{array}{l}\text { Adatsebesség } \\
(\mathrm{kbps})\end{array}$ & $\begin{array}{l}\text { Csatornák } \\
\text { száma }\end{array}$ & $\begin{array}{l}\text { Chip } \\
\text { sebesség }\end{array}$ & $\begin{array}{l}\text { Szimbólum } \\
\text { sebesség } \\
(\mathrm{ksym} / \mathrm{sec})\end{array}$ & Moduláció \\
\hline $2,4 \mathrm{GHz}$ & ISM & Világ & 250 & 16 & 2000 & 62,5 & O-QPSK \\
\hline $868 \mathrm{MHz}$ & ISM & Európa & 20 & 1 & 300 & 20 & BPSK \\
\hline $915 \mathrm{MHz}$ & ISM & Amerika & 40 & 10 & 600 & 40 & BPSK \\
\hline
\end{tabular}

1. táblázat IEEE 802.15.4 Zigbee frekvenciatartományai [15]

A Zigbee eszközök ütközés elkerülö, vivő érzékeléses, többszörös hozzáférést kezelő eljárást alkalmaznak (CSMA-CA ${ }^{20}$ ). A Zigbee képes kezelni egyedi 64 bites címet, illetve 16 bites hálózati címet, amely révén megközelítőleg 65 ezer cím osztható ki 256 alhálózatban. A 6LoWPAN ${ }^{21}$ címkompressziós eljárásnak köszönhetően képes IPv6 címek kezelésére is a rendszer [16] [17].

Energiamenedzsment szempontjából úgy alakították ki a protokollvermet és az alkalmazott protokollokat, hogy a technológia kis energiafelhasználást képes biztosítani, mindezt alacsony gyártási költségek mellett. Az eszközök müködését tekintve két állapotot különböztetünk meg az alvó és aktív állapotot. A szenzorok kommunikációs egységei idejük nagy részét alvó állapotban töltik, és alkalmazásuk mindössze 0,1\%-át töltik aktív állapotban.

Hálózatszerezés szempontjából a Zigbee technológia képes mesh hálózatok kialakítására, melyben a kommunikációs egységek három különböző szerepet tölthetnek be. Vannak a végpontok, melyeket a szenzorokhoz érdemes illeszteni. Itt alacsony energia felvétel mellett képes az egység az adatait megosztani a hálózattal. A végpontok routerekhez kapcsolódnak csillag topológiát kialakítva. A routerek szerepe kettős. Egyrészről végzik az alhálózatuk lekérdezését, mely során beacon jelekkel megszólítják a végpontokat, melyek egyenként egy 30 ms-os időrésben válaszolnak. A routerek energiafelhasználása már lényegesen nagyobb a végpontokhoz képest, az eltérő aktivítási idő miatt. A routerek másik feladatköre, csomóponti adatbázis, tranzakciós adatbázis, párosítási tábla kezelése, a hálózat többi forgalomirányítójához való kapcsolódás, és ezáltal a mesh topológia kialakítása, továbbá ezen hálózatoknak van még egy további kitüntetett szereplője a „koordinátor”, amely a mesh topológiába összekapcsolt hálózat koordinálását végzi. A koordinátorok és routerek is csatlakozhatnak szenzorokhoz. Valamint a Zigbee technológia lehetőséget nyújt logikai

\footnotetext{
${ }^{17}$ Media access Control

${ }^{18}$ Indstrial, Scientific and Medical

${ }^{19}$ Direct Sequence Spread Spectrum

${ }^{20}$ Carrier-sense multiple access with colision avoidance

${ }^{21}$ IPv6 over Low-Power Wireless Personal Area Network
} 
egyenrangú pont-pont (peer to peer) kapcsolatok létrehozására. Ez a WBAN hálózatokban, akkor hasznos például, ha két szenzort (szenzorokat) „ÉS” kapcsolatba kötünk egymással.

Biztonsági szempontból a fizikai rétegnél megemlített DSSS révén zavarállóságot, és alacsony felderíthetőséget biztosít [18] [19]. A Zigbee hálózat MAC szintü AES titkosítást alkalmaz. A MAC végzi a biztonsági feldolgozást, amelyhez a biztonsági kulcsot és a kapcsolódó szolgáltatásokat a felsőbb rétegek végzik.

Napjainkban már a Zigbee gyakorlati alkalmazásaival találkozhatunk WBAN hálózatokban, elsődlegesen EKG, pulzoximéter, és vérnyomás szenzorok hálózatba szervezése tekintetében [20] [21].

\section{WBAN HÁLÓZATOK ALKALMAZÁSI LEHETŐSÉGEI}

Megítélésem szerint a WBAN hálózatok a katonai alkalmazás szempontjából két nagy csoportba oszthatók. Egyfelől a müveletekben résztvevő katonák harcképességének nyomon követésére, melynek célja a fittség, a fiziológiai tulajdonságok alapján objektíven mérhető jó közérzet és a normálistól eltérő egészségi állapot monitorozása (health, wellness, fitness), továbbá a sérülések, harcképtelenné válás diagnosztizálása, és információk szolgáltatása az elsősegélynyújtáshoz. Ez egyedi, a mindennapos felhasználás során alkalmazható, hordható, ergonomikus kialakítású szenzorhálózatot jelent. A WBAN rendszerek másik felhasználási lehetősége a sérültek, harcképtelen személyek nyomon követése az első szakszerü segítségnyújtástól az egészségi kiürítésen (MEDEVAC ${ }^{22}, \mathrm{CASEVAC}^{23}$ ) keresztül a magasabb szintü egészségügyi ellátásig, rehabilitációig. Ezen célfelhasználás technikai eszközei kiegészíthetik az állandóan használt szenzorhálózatot (pl.: az egészségügyi kiürítés során), vagy fel is válthatják azokat (pl.: rehabilitáció). A magasabb szintű ellátás és rehabilitáció során a szenzorhálózat kiegészülhet invazív és non-invazív technikákat alkalmazó mintavételezési eljárásokkal.

Egy általam elgondolt Zigbee-t használó WBAN hálózat sematikus rajza a következő ábrán látható. Az ábrán a bal oldali hasábban található pontok a testfelületen elhelyezkedő szenzorok kommunikációs egységei.

A lenti ábrán egy harcászati kisalegység (raj) egyéni egészségi állapotellenőrzés és -jelentés rendszere hálózatának logikai kapcsolódási vázlata látható. Az egyes harcosok testfelületén kialakított Zigbee WBAN hálózaton keresztül összegyüjti az egészségi adatokat. Az ábrán a routerek csillagtopológiában füzik fel a végpontokat, melyet folyamatos vonallal jelöltem. A logikai topológiában az egyes végpontokat lehetséges összekötni egymással, ezzel akár logikai „ÉS” kapcsolatot alakíthatunk ki a szenzorhálózatunkban (szaggatott vonal). A Zigbee koordinátor az adatokat továbbítja az egyes harcos WPAN hálózatának részét képező adatfeldolgozó és tároló egység Zigbee interfészéhez. Ezt a kommunikációs egységet, mint már említettem célszerü a katona magasabb rendü hálózatokba csatlakozó kommunikációs termináljába integrálni (pl.: harcászati rádió, TETRA terminál, kilépési pont az $\mathrm{MH} \mathrm{KCEHH}{ }^{24}$ felé [22] stb.).

\footnotetext{
${ }^{22}$ Medical Evacuation - Egészségügyi kiürítés

${ }^{23}$ Casualty Evacuation - Sérültek kiürítése

${ }^{24}$ Magyar Honvédség Kormányzati Célú Elkülönült Hírközlő Hálózata
} 


\section{Szenzorhálózatok adatainak áramlása a különböző hálózati szinteken keresztül}

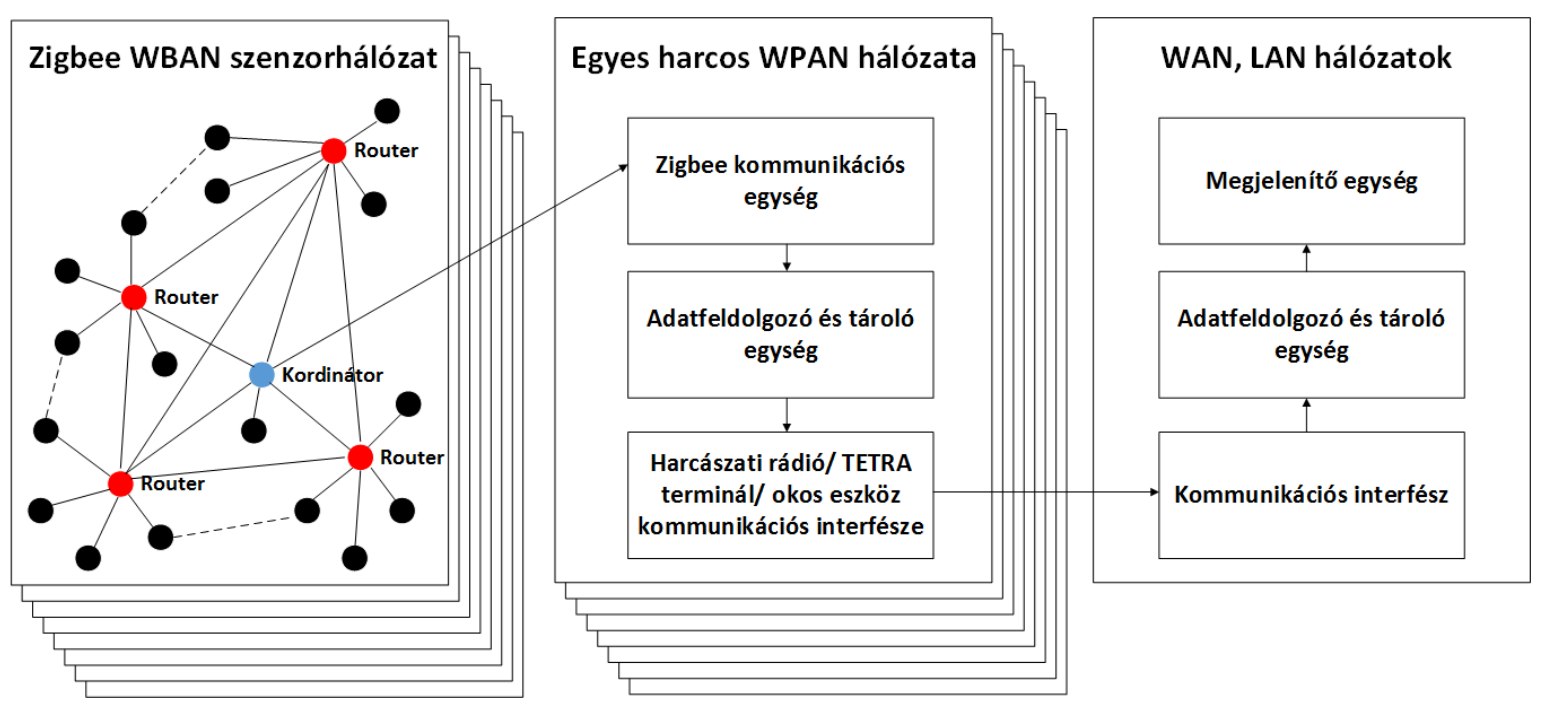

3. ábra Szenzorhálózatok adatainak áramlása a különböző hálózati szinteken keresztül (szerző)

Ebben a kommunikációs egységben kerülne elhelyezésre a Zigbee interfész, a szenzorhálózatból érkező személyi egészségügyi adatok feldolgozását végző és tároló egység, illetve a magasabb rendü hálózatok elérését biztosító kommunikációs interfész. Ez a rendszer kiegészülhet a személyi egészségügyi adatok megjelenítésére szolgáló modullal (pl.: aktuális pulzus, vérnyomás, stb.). Az egyéni egészségi állapotellenőrzés és -jelentés információkat a WPAN hálózatból lehetőség lenne lokális (pl.: raj-szakasz harcjármüvekben elhelyezett szerverek) illetve távoli hálózatokba (pl.: zászlóalj harcvezetési központban elhelyezett szerverek) továbbítani. Ezeken a szinteken több személyre kiterjedően lehet elvégezni az adatok feldolgozását, tárolását, nyomon követését, megjelenítését, szoftverek és esetlegesen mesterséges intelligencia támogatásával az adatokból az egészségügyi szakszemélyzetet, valamint a parancsnokok és törzseiket támogató információkat lehet képezni. Ezen szerverek, kommunikációs és megjelenítő egységek elhelyezésre kerülhetnek szakasz, század szinten gépés harcjárművekben, ahol a szakasz-, századparancsnokok és felcserek juthatnak fontos információkhoz a személyi állományról. A távoli hálózatokban, például egy zászlóalj-, dandár vezetési pontokon, esetlegesen a magasabb egészségügyi ellátást végző kórházakban (ROLE2, -3), szintén kiértékelhető az állomány egészségi helyzete. A megszerzett közel valós idejű információk jól támogatják az egészségi kiürítés megszervezését, a pihentetéshez, rehabilitációhoz nyújtanak tervezési adatokat, végső soron a saját állományról rendelkezésre álló objektív mérési eredményeken alapuló szenzorhálózatból nyert információk, elősegítik a saját információs fölényünk kialakítását.

\section{KÖVETKEZTETÉSEK}

Eddigi kutatómunkám során már az erőkövetés $\left(\mathrm{BFT}^{25}\right)$ számos kihívását feltártam, és tettem rá megoldási javaslatokat. Részben ezen eredményeim indukálták szenzorhálózati kutatásaim megkezdését. A sokak által predesztinált „,IoT ${ }^{26}$ BUMM” és vele a minden az interneten $\left(\mathrm{IoE}^{27}\right)$ elöretörésével, a nem túl távoli jövőben már kézzel foghatók lesznek a minket körülvevő, hálózatba integrált, tömegesen jelenlévő szenzor rendszerek. Ezek alól természetesen nem

\footnotetext{
${ }^{25}$ blue force tracking

${ }^{26}$ Internet of Things

${ }^{27}$ Internet of Everething
} 
lesznek kivételek a WPAN-WBAN méretü hálózatok, és az egészségügyi adatok közel valós időben történő nyomon követhetösége sem.

Jelen tanulmányomban feltártam az egyéni egészségi és állapotellenőrző és -jelentő rendszert támogatni képes egészségügyi eljárások, szenzorok körét, továbbá ezen szenzorokat hálózatba integrálva, bemutattam a WBAN hálózatok perspektivikus alkalmazási lehetőségeit az erőkövetési adatok megosztását illetően. Ezen vezeték nélküli rádiófrekvenciás eljárással összekapcsolt hálózatnak egyik lehetséges protokollja lehet a ZigBee.

\section{FELHASZNÁLT IRODALOM}

[1] GÁCSER Zoltán mk. őrnagy: A katona harci képességeit növelö korszerü, hálózatba integrált egyéni felszerelésrendszerének kialakitási lehetőségei a Magyar Honvédségben, $\mathrm{PhD}$ értekezés, Budapest, 2008. p. 130. URL: http://uninke.hu/downloads/konyvtar/digitgy/phd/2008/gacser_zoltan.pdf (Letöltés ideje: 2017. október. 28.)

[2] HAIG Zsolt- VÁRHEGYI István: Információs müveletek II. kötet, egyetemi jegyzet, ZMNE 2004. p.

[3] ATHERTON Kelsey: Take A Look At Russia's New Armata Tank [Infographic], 2015. április 1. url: https://www.popsci.com/look-russias-new-tank-infographic (Letöltés ideje: 2019.02.20.)

[4] KÁROLY K.: A Magyar Honvédség helymeghatározó és jelentő rendszer kialakításának jogszabályi kérdései, In: Társadalom és Honvédelem, XIX. évf. 2. szám, 2015. pp. 249260. ISSN 1417-7293

[5] dr. Joó Péter őrnaggyal végzett mélyinterjú, 2015.06.10. Koszovó, Pristina

[6] KHAN Y Jamil, YUCE R Mehmet: Wireless Body Area Network (WBAN) for Medical Application, In.: New Development in Biomedical Engineering, 31. fejezet Szerk.: CAMPOLO Domenico, New York, USA, 2010. ISBN 978-953-7619-57-2 DOI 10.5772/7598 pp. 591-628. URL: http://cdn.intechopen.com/pdfs/9103/InTechWireless body area network wban for medical applications.pdf (Letöltés ideje: 2017. október 28.)

[7] MCGRATH Michael, NÍ SCANAIL Cliodhna: Sensor Technologies, Health Care, Wellness, and Enviromental Applications, Apress Open Kiadó, New York, USA 2014. ISBN-13 978-1-4302-6014-1

p. 321.

URL: http://www.realtechsupport.org/UB/CM/presentations/SensorTechnologies.pdf (Letöltés ideje: 2017. október 28.)

[8] MÉSZÁROS Csaba: Milyen lesz az okosruha divat? In: COMPUTERWORLD, 2015.10.08. URL: https://computerworld.hu/uzlet/milyen-lesz-az-okosruha-divat168378.html (Letöltés ideje: 2019.01.09.)

[9] STUBÁN Norbert: Vezeték nélküli magzati pulzioximéter megvalósitása, $\mathrm{PhD}$ értekezés, BME, VIK, $\quad$ BMEETT, 2009. p. 91. URL: https://repozitorium.omikk.bme.hu/bitstream/handle/10890/865/ertekezes.pdf?sequence =1 (Letöltés ideje: 2017. október 28.)

[10] WENT István: Élettan, Medicina Kiadó 1962. pp. 112-147.

[11] KESZTYUUS Lóránd: Kórélettan, Medicina Kiadó, 1975. ISBN 963240016X

[12] GANONG William F.: Az orvosi élettan alapjai, Medicina Kiadó, 1990. ISBN 9632417836 
[13] BALLAI Vince: Nem a csórók menedéke a magyar sereg (2013.01.31. 16:53), In: Origo url: http://www.origo.hu/itthon/20130130-sorkatonasag-es-hivatasos-katonasag.html (Letöltés ideje: 2019.02.20.) - fotó: Koszticsák Szilárd - MTI

[14] IEEE Std. 802.15.4, 2003 Edition, http://standards.ieee.org/catalog/olis/lanman.html (Letöltés ideje: 2017. október 31.)

[15] KOVÁCS Balázs - VIDA Rolland: A Zigbee technológia, In.: Híradástechnika, 2003. november, pp. 9-12. ISSN 0018-2028 URL: http://web.tmit.bme.hu/ vida/cv/zigbee.pdf (Letöltés ideje: 2017.11.01.)

[16] TURI Gábor: Rádióhálózatok Zigbee- adatátvitel alapján, In.: Magyar Elektronika, 2008/ 1-2, pp. 34-35.

[17] Zigbee Alliance, URL: http://www.zigbee.org (Letöltés ideje: 2017. október 31.)

[18] NÉMETH A, HORVÁTH A, GULYÁS A: Ultra wideband data channels for special operations forces, In: Hadmérnök, VIII (1) pp. 154-165. (2013), ISSN 1788-1919

[19] GULYÁS Attila: Gondolatok az adatátviteli rendszerek fejlődéséről, In: Seregszemle, 2017/2. pp. 162-188. ISSN 2060-3924

[20] JAIN Anupam - HALDER Minakshi: An Overview of Wireless Body Area Network (WBAN) using Zigbee Technology, In.: International Jurnal of Scientific Development and Research (IJSDR) Vol. 1. Issue 5, 2016. május ISSN 2455-2631 pp. 888-895.

[21] Zigbee Wireless Sensor Application for Health, Wellness and Fitness, Zigbee Alliance, 2009. március p. 15. URL: http://www.zigbee.org/zigbee-fordevelopers/applicationstandards/zigbee-health-care/ (Letöltés ideje: 2017.11.20.)

[22] JOBBÁGY Szabolcs: A Magyar Honvédség Kormányzati Célú Elkülönült Hírközlö Hálózata, In: Hadmérnök XII. évf. 3. szám 2017. szeptember pp. 223-236. ISSN 17881919 